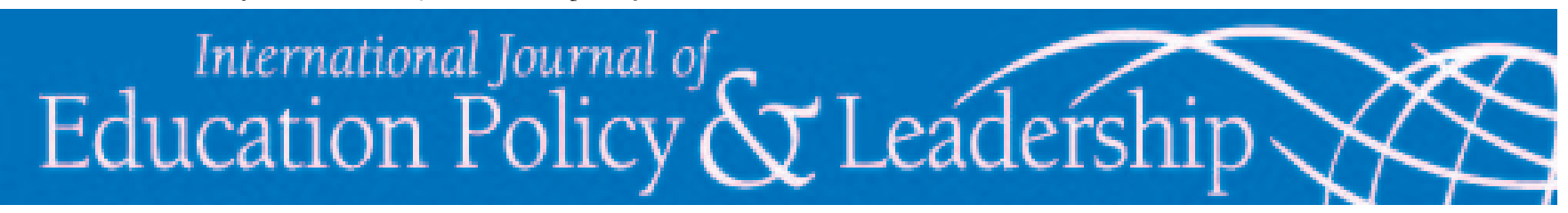

\title{
Improving Student Achievement: Can 9th Grade Academies Make A DIFFERENCE?
}

\author{
RONALD ANTHONY STYRON \\ The University of Southern Mississippi \\ EDdie J. PEASANT \\ Clinton High School
}

\begin{abstract}
This study focused on student achievement in ninth grade schools or academies compared to ninth grade students enrolled in traditional high schools. Student achievement was measured by standardized test scores. Other variables tested were gender and ethnicity. All students used in this study were enrolled in the ninth grade during the 2005-2006 school year at one of six schools selected for this research. Participants were enrolled in Algebra I and/or Biology I course(s) and therefore took the standardized Subject Area Test (SAT) in these disciplines. Data indicated students enrolled in ninth grade academies scored significantly higher then ninth graders enrolled in traditional high schools on both the Algebra I and Biology I test. Further analysis of data revealed significant differences based on ethnicity in achievement of Biology I students in the ninth grade academies when compared to the Biology I students in the traditional high schools. The African American students in the ninth grade academies had a higher mean score on the Biology I SAT than Caucasian and African American students enrolled in the traditional high schools. Additionally, the Caucasian students in the ninth grade academies scored only .03 higher than the mean score of African American students in the ninth grade academies.
\end{abstract}

Styron, R. \& Peasant, E. (2010). Improving Student Achievement: Can 9th Grade Academies Make a Difference? International Journal of Education Policy and Leadership 5(3). Retrieved [DATE] from http://www.ijepl.org.

\section{Introduction}

In today's climate of school accountability, it is of paramount importance for educators to search for ways to improve student achievement. Therefore, the purpose of this study was to determine if there was a significant difference between the academic achievement of students who attended 9th grade academies and those who attended traditional high schools.

Over the past several decades, school administrators have strived to find solutions for assisting 9th grade students in making a smooth transition to high school as those students dealt with many challenges during the peak of their adolescent years. School administrators have found that students are placed in situations that they are not yet prepared to deal with. These situations, which may have included academic and social challenges, often result in low student achievement and/or dropouts (Olfman, 2005). Stimulated by the No Child Left Behind Act (NCLB, 2001), educators and legislators are now compelled to measure student achievement and success by standardized test scores. The emphasis on test scores has led to greater school accountability. The mandates of NCLB have led the state described in this study to develop a subject-area testing program for high school students that generated the Algebra I and Biology I test data used for analysis.

A committee of distinguished educators created the test, which included four subject areas: Algebra I, Biology I, English II, and U.S. History. District superin-

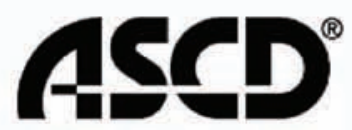

LEARN. TEACH. LEAD.
SIMON FRASER UNIVERSITY

THINKING OF THE WORLD

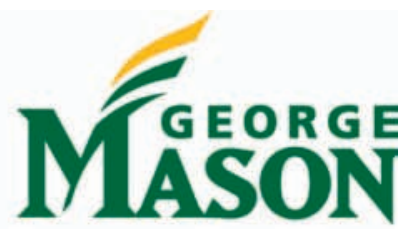


tendents were asked to nominate their most exemplary teachers in each of these subjects, and from this nominee pool, the State Department of Education selected 30 teachers for each subject area committee. Representation was by congressional district, district accreditation level and ethnicity. Once selected, the teacher committees directly participated in all phases of test development.

The Algebra I Subject Area Test measures student knowledge and skill level in applied algebra. The test consists of 65 multiple-choice items. Test items contain charts, graphs, or diagrams that the student uses to determine the correct answer. The committee integrated questions from the following assessment strands throughout the test: Patterns, Relations, and Functions; Equations and Inequalities; Polynomials; Formulas in Problem Solving; Slope; and Probability. The Biology I Subject Area Test measures student knowledge of basic biological concepts, the use of science skills, and the application of biological concepts to real-world problem solving and decision making. Students must interpret data, apply concepts, draw conclusions, and explain their own ideas. The test consists of 89 multiple-choice items including charts, diagrams, and graphs. Questions from the following assessment strands were integrated throughout the test: Chemical Basis of Life; The Cell; Genetics and the Molecular Basis of Heredity; Natural Selection and Diversity; Ecology; and the Nature of Science. Students must meet or exceed the minimal required test score in order to satisfy graduation requirements. Students in the ninth grade take the biology and algebra portions of the subject area tests. To a great extent, because of this measure of high stakes testing and connection to graduation requirements, the 9th grade year has become a critical step in establishing a sound foundation for high school academic success.

This study focused on the academic achievement of 9th grade students in traditional high schools where 9th graders were integrated into all courses with 10th through 12th graders, and had no separate 9th grade facility; and 9th grade students who attended a 9th grade academy where courses were housed in a separate facility. Ninth grade academies that participated in this study utilized block scheduling, team teaching, and professional learning communities. ed:

Research questions used to guide this study includ-

1) Was there a significant difference in Algebra I Subject Area Testing Program scores between freshman students who attended 9th grade academies and freshman students who attended traditional high schools?

2) Was there a significant difference in Biology I Subject Area Testing Program scores between freshman students who attended 9th grade academies and freshman students who attended traditional high schools?

\section{Related Literature}

\section{Academic Culture}

Middle school experts Lounsbury and Johnston (1985) conducted an extensive study of 9th graders across the United States and discovered a disturbing discrepancy between school policies and practices and the developmental needs of 14-year-old students. Classroom instruction was found to be teacher-centered with passive involvement of students. Ability grouping, 40- to 50-minute classes, and tracking were also common practices found in 9th grade settings. Lounsbury and Johnston also cited high schools as lacking in adequate guidance for 9th grade students to help them adjust both academically and socially. Based on their findings, they predicted the 9th grade would "continue to drift" and "mirror the worst of outmoded high school practices that do little to foster positive learning for all students" (p. 43).

A study of high school reform by Wheelock (1993) produced similar findings. Students who became disengaged, discouraged, and were unable to develop strong bonds with teachers were the most vulnerable to failure. In addition, other factors such as tedious lessons, overcrowded classrooms, and indifferent teachers contributed to students' lack of success in the 9th grade.

The inability to meet academic expectations can also lead to an increase in dropout rates. For example, students at risk for school failure report that their schoolwork is "too difficult" and that they lack the skills needed to complete homework (Crist, 1991). An investigation conducted by Stanley, Slate, and Jones (1999) tracked the study skills of 255 9th grade students in honors and college prep classes at a southeastern high school. Participants completed a true-false study habits inventory that consisted of 58 items. The inventory was designed to explore various study habits and note-taking behaviors. The three areas of weaknesses detected were: (a) failure to recopy lecture notes soon after class, (b) failure to use any special method for learning new terms, and (c) waiting until the last minute to study for tests. 
The results also indicated that students frequently read several pages of text without knowing what they had read and seldom utilized advanced organizers, charts, or diagrams to focus their reading and reviewing.

In an environment with numerous academic choices to be made, students develop an unenthusiastic attitude toward high school and fail to remember the importance of graduating and receiving a high school diploma. "Many adolescents develop a more negative view of themselves than they had in middle school; and they feel less competent to handle the academic and social demands of school" (Hertzog, Morgan, Diamond, \& Walker, 1996, p. 7). They also found students independently devising their class schedule with a lack of guidance by teachers to assist them in making astute academic choices. This led to increased dropout rates.

Countless 9th grade students struggle with the transition from middle school to high school because of higher expectations from teachers, additional homework, and the freedom of selecting the most appropriate classes and activities to prepare them for life after high school. Furthermore, students indicate they need to know more about high school, the classes they need to take, directions for finding their way through the building, and how to locate classes in the new setting. Students need to understand the details of how classes are planned and to become knowledgeable about academic and graduation requirements. When challenges arise, students need information regarding resources to assist them in solving problems and resolving important issues (Reyes, Gillock, Kobus, \& Sanchez, 2000). For example, "choosing to take a particular section of Algebra I may track a student into the general curriculum when he or she intended to enter the college preparatory curriculum" (Mizelle, 1995, p. 57). This decision could lead students to a lack of college preparatory classes or vocational courses needed to provide them with appropriate training before entering the workforce after graduation.

The selection of extracurricular activities can also be critical, because participation in these activities may sometimes earn students scholarships and other financial assistance. While participation in school activities by 9 th graders was helpful, Isakson and Jarvis (1999) often found a decline in participation in these important activities. Fulk (2003) also concluded that students who participated in school activities more readily identified with the school's mission and culture. Students who did not participate in school activities began to feel alienated and marginalized. However, because students may already feel overwhelmed by academic demands, they may not be able to find the time for additional activities.

\section{Factors Influencing Student Achievement}

School size. As the size of schools in the United States increases, so does concern regarding the impact of school size on student achievement. While the number of schools in the United States has increased slightly from 23,000 in 1930 to 26,000 in 2000, the number of students in these schools increased dramatically from 4.4 million to over 13 million (United States Department of Education, 2000).

Some studies have failed to show a relationship between school size and student achievement (Lindsay, 1984; Jewell, 1989; Lee \& Smith, 1997) but research conducted by Pool (2002) and Bracey (2001) indicated that schools with lower student enrollment had greater levels of student achievement than similar schools with higher enrollment. These findings were consistent with those of Lee and Loeb (2000) who found in a study of Chicago schools that small schools with an enrollment of 400 students or less had higher levels of student achievement than larger schools. Black (2006) examined several projects that indicated that communities with a large segment of the population at or below the poverty line benefited from small schools.

Johnson, Howley, and Howley (2002) examined the scores of seven state-required tests in Arkansas and found that small schools in high poverty areas produced higher scores than their larger counterparts in similar environments. Their research also indicated that small schools lessened the disparity in achievement between students from affluent and poor communities and could also be more effective in combating the effects of poverty.

Ethnicity, gender and student achievement. There has been an ongoing debate regarding the effects of ethnicity and gender on student achievement. In a study conducted by Greenfield (1998), greater differences in science achievement were documented by ethnicity than by gender. In a study of quantitative research pertaining to mathematics achievement, (Tate, 1997) found that although the achievement gap is lessening, there is still a disparity between white and black students. He also found that while male students outperformed female students, gender differences were not significant.

National Assessment of Educational Progress (NAEP) test scores from 1990-2003 showed males scor- 
ing higher than females in both the 4th and 8th grade. For the same testing period, 4th and 8th grade Asian students recorded the highest scores. Scores of white students were below those of Asian students, but above Hispanic student scores. Black students recorded the lowest scores. Furthermore, students eligible for free or reduced-price school lunch scored lower than those who were not eligible (Braswell, Daane, \& Grigg, 2003).

\section{Traditional High Schools}

Schools have drastically changed since the early 20th century, when it was common for children to receive an education in one-room schoolhouses where teachers had the difficult task of educating students of various age groups at the same time. A single teacher was responsible for teaching all the students reading, writing, arithmetic, and history. Only half of school-age children 5 to 19 years old attended school. Most of those who continued their education only completed the 8th grade and an even smaller number, 6.4 percent, graduated from high school (Kennedy, 1999; Hufstedler, 2002). They were also segregated into two separate and distinct school systems, one for whites and another for blacks. It was commonplace for children to pass a nearby school on the way to another school with other children of the same race (Kennedy, 1999). This practice was allowed because of the legal doctrine of "separate but equal" established by the United States Supreme Court in 1896, which allowed students to be separated by race (Reutter, 1994).

The high school movement in the United States marked the beginning of the traditional high school. The movement began in 1910 and lasted until 1940. The United States led the development and financing of secondary education. It was during the high school movement that the number of high schools increased tremendously. But only 9 percent of the students attending high school earned a diploma in 1910. By 1935, the percentage of students receiving high school diplomas had increased to 40 percent (Goldin \& Katz, 1999). During the Great Depression, the stock market crashed, leaving millions of adults and teenagers jobless; the resulting lack of gainful employment encouraged teenagers to remain in high school. Enrollment in high schools increased to 6.6 million by 1940. After World War II, millions of Americans married, bought houses, and began their families. Because of the ensuing population increase, enrollment in public high schools increased from 25.1 million in 1950 to 46.1 million in 1971. Additionally, 46 percent of the nation's high schools were built between 1950 and 1969 (Kennedy, 1999).
The launching of the Soviet Union's space satellite, Sputnik, had a great effect on high schools in the United States. This event led to the creation of a rigorous high school math and science curriculum.

Today, high schools tend to be focused on disjointed instruction held in highly depersonalized settings with large student populations. Strained resources have also contributed to a lack of attention to individual needs (Smith \& DeYoung, 1988).

\section{Academies}

According to Stern, Raby, and Dayton (1992), the academy concept dates back to 1969 , when it was created to improve academics and reduce dropout rates by integrating a rigorous academic program with a strong career focus. Academies are typically found within a larger school, have small learning communities, incorporate academic and vocational curricula, and have partnerships with community employers. Other characteristics of 9th grade academies include the use of separate buildings, team teaching, and block scheduling (Legters, 2000). According to Kemple and Snipes (2007, p.7) "Academies stand at the intersection of several major education reforms aimed at transforming high schools into nurturing, productive places where students learn and grow and are prepared for careers in an economy that demands high skills and adaptability." Today, there are more than 1,500 varied academies throughout the United States as school districts have created academies that meet their own specific needs. This number includes 128 9th-grade-only academies (National Center for Educational Statistics, 2004).

Concerns about providing a more supportive environment for early adolescents fueled the middle school movement, which advocated replacing junior high schools serving grades 7-9 with middle schools comprising grades 6-8. Over the last 20 years, the number of middle schools has grown from 3,916 to 10,205 (NCES, 2004). The shift in grade levels resulted in many 9th grade students moving from junior high to high schools.

Ninth graders found within traditional high schools have struggled to attain high levels of academic achievement. During the mid-1990s, high schools had a 70 percent attendance rate, student apathy and unruliness, and high numbers of academic failures. Administrators and teachers began to rethink the design of high schools that encompassed grades 9 through 12 and are second-guessing the wisdom of subjecting 14-year-olds to the more intense academic and peer pressures of high school (Black, 2004). They are looking for solutions to these 
problems that include the 9th grade academy model (George, Stevenson, Thomason, \& Beane,1992).

Mizelle (1995) found that students had a more successful transition when they stayed together using the cohort concept. Their success was enhanced because they remained with the same teachers through multiple grade levels and experienced more hands-on, real-life learning activities, integrated instruction, and cooperative learning methodologies. These students were more successful than students from the same school who had a traditional school experience. Starkman, Scales, and Roberts (1999) found data that indicated a strong relationship between academic success and social competence, and the ability of students to adapt to various environments. Ninth grade academies must be able to provide an atmosphere of emotional caring along with intellectual challenge. This led some researchers to conclude that student progress on social competence, even more than intellectual measures, could be the best primary measure of academic success (Starkman et al., 1999).

\section{Methodology}

This study assessed statistical differences between 9th grade academies and traditional high schools. For the purpose of this study, 9th grade academies were defined as institutions where students attended only elective courses with students in grades 10 through 12 and were housed in a separate facility. Block scheduling, team teaching, and professional learning communities were also found at the academies used for this study. Traditional high schools were defined as institutions where 9th graders were integrated into all courses with students in grades 10 through 12 and had no separate facility. The study was conducted in a state within the southern region of the United States. The measure of effectiveness of 9th grade academies was based on academic achievement, as defined by students' performance on the Algebra I and Biology I subject area tests described previously. These tests were selected because they were administered during the 9th grade within the schools participating in this study.

\section{Participants}

The subject group consisted of 50 randomly selected, first-time 9th grade students who attended traditional high schools and 50 randomly selected first-time freshman students who were enrolled in 9th grade academies. Participants of this study followed their normal school attendance assignments. School assignments were made by the school district and were based on facility capacity and the residence of students as relative to the geographic location of the school. Participants were enrolled in Biology I and/or Algebra I and had taken the Subject Area Test for these courses during the spring semester, near the end of their 9th grade school year. The group consisted of female and male students from various ethnic backgrounds including black, white, Asian, and Hispanic.

Six schools from three different regions of the state (southern, central, and northern) with similar demographics were used for this study. All six schools had a population of 60 percent or more who qualified for free or reduced lunch. Each traditional high school had a minimum enrollment of 1,000 students in grades 9 through 12. Each 9th grade academy had a minimum enrollment of 350 students. Block scheduling was utilized for academic and elective courses at all school sites. All school sites offered advanced placement courses, special education programs, and extracurricular activities including band, choir, clubs, and all high school sports.

\section{Data Collection}

The researchers collected archival data for each first-time 9th grade student for four variables: scores from the Algebra I SATP test and the Biology I SATP test, ethnicity, and gender. The names and identification numbers of students were excluded. The response rate of participants was no less than 95 percent. Each school had 90-110 students completing the selected tests. A total of 600 student scores were analyzed. The relatively high response rate was the result of state mandates.

\section{Analysis of Data}

The statistical analysis software Statistical Package for the Social Sciences (SPSS) was used to perform an independent $\mathrm{t}$ test to determine if there was a statistically significant difference at the .05 alpha level in achievement between student participants attending 9th grade academies and student participants enrolled in traditional high schools.

\section{Data}

Table 1 (page 6) includes data pertaining to gender. Although there were more females than males, the difference was less than 5 percent when 9th grade academies were compared to traditional high schools.

Table 2 (page 6) includes data pertaining to ethnicity. There were four ethnic groups found within this study: black, white, Asian, and Hispanic. The number of white students in traditional high schools was more than twice the number of other ethnic groups, although the number 
Table 1: School Demographics for Gender in 9th Grade Academies and Traditional High Schools for the 2005-2006 School Year

\begin{tabular}{|c|c|c|c|}
\hline Gender & $\begin{array}{l}\text { 9th Grade } \\
\text { Academy }\end{array}$ & $\begin{array}{l}\text { Traditional } \\
\text { High School }\end{array}$ & Total \\
\hline Female & 178 & 165 & 343 \\
\hline$\%$ & $59.3 \%$ & $55 \%$ & $57.2 \%$ \\
\hline Male & 122 & 135 & 257 \\
\hline$\%$ & $40.7 \%$ & $45 \%$ & $42.8 \%$ \\
\hline
\end{tabular}

of black students tested in the 9th grade academies outnumbered the white students by 5 percent. Data also indicated that gender was not significant in this study.

The mean score, found in Table 3 (page 7), was higher in Algebra I and in Biology I for 9th grade academies than for traditional high schools. Biology I mean scores were higher than Algebra I mean scores for their respective groups. The difference in these scores may be due to the fact that students were not allowed to take Biology I in the 8th grade but higher-achieving students were allowed to take Algebra I in the 8th grade. Therefore, these advanced students did not have their Algebra I scores credited to their high school or 9th grade academy. These calculation/reporting differences may help explain the differences in mean scores between the Algebra I and Biology I tests.

Standard deviations were largely due to the wide range of scores found in both groups. There were several students in 9th grade academies and in traditional high schools who scored perfect scores of 500 . The lowest score was 282 .

\section{Tests of Hypotheses}

Hypotheses were tested at the .05 level of significance. The results of the tests were as follows:

$\mathrm{H1}$ : There was a significant difference in Algebra I scores between freshman students who attended 9th grade academies and freshman students who attended traditional high schools $[t(248)=3.47, p=.001]$. Therefore, this hypothesis was accepted. The mean of Algebra I scores was higher for the students in 9th grade academies than the mean scores for 9th grade students in traditional high schools. Table 3 represents the means used to test Hypothesis 1.

$\mathrm{H} 2$ : There was a significant \% difference in Biology I scores between freshman
Table 2: School Demographics for Ethnicity in 9th Grade Academies and Traditional High Schools for the 2005-2006 School Year

\begin{tabular}{llll} 
Ethnicity & $\begin{array}{l}\text { 9th Grade } \\
\text { Academies }\end{array}$ & $\begin{array}{l}\text { Traditional } \\
\text { High Schools }\end{array}$ & Total \\
\hline Black & 156 & 80 & 236 \\
$\%$ & $52 \%$ & $26.7 \%$ & $39.3 \%$ \\
White & 141 & 207 & 348 \\
$\%$ & $47 \%$ & $69 \%$ & $58 \%$ \\
Asian & 2 & 8 & 10 \\
$\%$ & $.7 \%$ & $2.7 \%$ & $1.7 \%$ \\
Hispanic & 1 & 5 & 6 \\
$\%$ & $.3 \%$ & $1.7 \%$ & $1.0 \%$ \\
\hline
\end{tabular}


Table 3: A Summary of Mean Scores and Standard Deviation of Algebra I and Biology I for 9th Grade Academies and Traditional High Schools

\begin{tabular}{llll} 
Test & Group & Mean & $\begin{array}{l}\text { Standard } \\
\text { Deviation }\end{array}$ \\
\hline Algebra I & $\begin{array}{l}\text { 9th Grade } \\
\text { Academy } \\
\text { Traditional }\end{array}$ & 375.66 & 30.69 \\
Biology I & $\begin{array}{l}\text { High School } \\
\text { 9th Grade } \\
\text { Academy } \\
\text { Traditional } \\
\text { High School }\end{array}$ & 359.23 & 40.24 \\
\hline
\end{tabular}

Subject area test scores in Algebra I and Biology I range from 250-500. grade academies found in this study appeared to be more effective in terms of student achievement than the traditional high schools found in this study.

Several considerable differences emerged which favored the 9th grade academy concept. Students enrolled in 9th grade academies outperformed students found in this study. There was also a significant difference in the interaction $(\mathrm{p}=.006)$ of 9 th grade students from all schools found in this study with all 9th grade students from all ethnicities used in this study. This information is illustrated in Table 5 (page 8).

Biology I data appear to support the notion that 9th grade academies may enhance academic achievement, most notably for black students. There is no evidence supporting the same notion for Algebra I. This may be due, at least in part, to the fact that high-achieving students were allowed to take the Algebra I subject area test in the 8th grade; thus, these scores were not included with their high school scores.

\section{Limitations}

This work was limited by the narrow scope of those factors related to student achievement that were analyzed, the relatively brief time frame of the study, and the small geographic region selected for the study.

\section{Discussion}

The chief purpose of the 9th grade academy was to increase academic achievement for students during the critical transitional year from middle to high school. The 9th grade academy was also designed to provide adolescent students with the attention and support needed to get through this difficult period without the competition of peer pressure from older students found in the traditional high school setting. In some cases, the findings of this study showed significantly higher test results for students enrolled in 9th grade academies and, as a result, the 9th in traditional high schools in Algebra I by more than 15 enrolled in 9th grade academies also scored nearly 25 points higher on the subject area test in Biology I. Both white and black students scored significantly better on each of the subjects than the traditional high school groups.

For both white and black students, Biology I scores were significantly higher than Algebra I scores in 9th grade academies than in traditional high schools. Furthermore, Biology I scores for black students enrolled in 9th grade academies were 58 points higher than the scores for black students enrolled in traditional high schools. In addition, Biology I scores for black students found in 9th grade academies had a mean score that was only three-tenths of one point lower than the mean score of white students, while in traditional high schools the mean score for black students was 40.3 points lower than white student scores.

Haney, Madaus, Abrams, Wheelock, Miao, \& Gruia (2004) found the 9th grade experience a critical component in determining academic success for students. They

Table 4: A Summary of Means and Standard Deviation of Scores in Biology I for

\begin{tabular}{llccc} 
Group & \multicolumn{1}{c}{ Ethnicity } & Mean & $\begin{array}{c}\text { Standard } \\
\text { Deviation }\end{array}$ & $\mathrm{N}$ \\
\hline 9th Grade & Black & 400.07 & 54.33 & 46 \\
Academy & White & 401.00 & 47.47 & 53 \\
$\begin{array}{l}\text { Traditional } \\
\text { High School }\end{array}$ & Black & 342.07 & 54.50 & 41 \\
& White & 382.10 & 51.25 & 105 \\
Total & Black & 372.74 & 61.43 & 87 \\
& White & 388.44 & 50.66 & 158
\end{tabular}

Subject area test scores in Algebra I and Biology I ranged from 250-500. points on the subject area test. Ninth grade students Black and White Students 
also found that minority students enrolled in academies experienced a smaller achievement gap with white students. These findings are consistent with those found in this study.

The findings of this study are certainly noteworthy, as there are implications that may be of use to school leaders in terms of improving academic achievement, especially the academic achievement of black students. Closing the achievement gap between white and black students is of the utmost importance, as there is a considerable amount of research detailing the gap between their achievement scores (Braswell, Daane, \& Grigg, 2003). We suggest that the findings of this study substantiate a number of reasonable arguments to give serious consideration to the concept of 9th grade academies when creating school configurations. With the demands of the No Child Left Behind Act and the expectations of increased student achievement, it is of the utmost urgency that student performance improve at the pivotal 9th grade level. As documented in this study, student achievement of those enrolled in 9th grade academies did prove to be higher when compared to student achievement of 9th graders enrolled in traditional high school settings.

\section{Recommendations for Future Research}

The authors recommend that this study be: a) replicated to include other factors such as discipline and average daily attendance; b) replicated for 8th and 10th graders to generate longitudinal data; c) expanded to a state with a larger urban population than the state found in this study; d) expanded to include schools utilizing a schoolwithin-a-school concept; and e) Enlarge to include data pertaining to the number of students taking Algebra I in the 8th grade.

\section{References}

Black, S. (2004). The pivotal year. American School Board Journal, 191(2), 42-44.

Black, S. (2006). The right size school. American School Board Journal, 193(4), 63-65.

Bracey, G. (2001). Small schools, great stories. Phi Delta Kappan, 82(5), 413-414.
Braswell, J. S., Daane, M. C., \& Grigg, W. S. (2003). The nation's report card: Mathematics highlights 2003 (NCES 2004-451). Washington, DC: U.S. Department of Education, Institute for Education Sciences, National Center for Education Statistics.

Crist, K. (1991). Restoring opportunity for drop-outs. Equity and Excellence, 25(1), 36-39.

Fulk, B. (2003). Concerns about ninth-grade students' poor academic performance: One school's action plan. American Secondary Education, 31(2), 8-26.

George, P. S., Stevenson, C., Thomason, J., \& Beane, J. (1992). The middle school - and beyond. Alexandria, VA: Association for Supervision and Curriculum Development.

Goldin, C., \& Katz, L. (1999). Human capital and social capital: The rise of secondary schooling in America, 1910-1940. Journal of Interdisciplinary History, 29 (4), 683-723.

Greenfield, T. A. (1998). Gender, ethnicity, science achievement, and attitudes. Journal of Research in Science Teaching, 33(8), 901-933.

Haney, W., Madaus, G., Abrams, L., Wheelock, A., Miao, J., \& Gruia, I. (2004). The education pipeline in the United States, 1970-2004. Chestnut Hill, MA: National Board on Educational Testing and Public Policy.

Hertzog, C. J., Morgan, P. L., Diamond, P. A., \& Walker, M. J. (1996). Transition to high school: A look at student perceptions. Becoming, 7(2), 6-8.

Hufstedler, S. M. (2002). The once and future K-12. Phi Delta Kappan, 83(9), 684-689.

Isakson, K., \& Jarvis, P. (1999). The adjustment of adolescents during the transition into high school: A short-term longitudinal study. Journal of Youth and Adolescence, 28, 1. 
Johnson, J.D., Howley, C.B., and Howley, A.A. (2002). Size, Excellence, and Equity, a Report on Arkansas Schools and Districts. Athens, OH; Ohio University, College of Education, Educational Studies Department. Retrieved February 21, 2009 from http://www.ruraledu.org/articles.php?id=2068.

Kemple, J. J., \& Snipes, J. C. (2000). Career academies: Impacts on students' engagement and performance in high school. San Francisco: Manpower Demonstration Research Corporation.

Kennedy, M. (1999). A century of progress. American School \& University, 72(4), 6-10.

Lee, V. E., \& Loeb, S. (2000). School size in Chicago elementary schools: Effects on teachers' attitudes and students' achievement. American Educational Research Journal, 37(1), 3-31.

Lee, V. E., \& Smith, J. B. (1997). High school size: Which works best and for whom? Educational Evaluation and Policy Analysis, 19(3), 205-227.

Legters, N.E. (2000). Small learning communities meet school-to-work: Whole school restructuring for urban comprehensive high schools. In M. Sanders (Ed.), Schooling students placed at risk: Research, policy, and practice in the education of poor and minority adolescents (pp. 309-337). Mahwah, NJ: Lawrence Erlbaum.

Lindsay, P. (1984). High school size, participation in activities, and young adult social participation: Some enduring effects of schooling. Educational Evaluation and Policy Analysis, 6, 73-83.

Lounsbury, J., \& Johnston, J. H. (1985). How fares the ninth grade? A day in the life of a 9th grader. Reston, VA: National Association of Secondary School Principals.

Mizelle, N. B. (1995, April) Transition from middle school into high school: The student perspective. Paper presented at the annual meeting of the American Educational Research Association, San Francisco. National Center for Education Statistics [NCES]. (2004). The condition of education 2004. Retrieved March 10, 2008, from http://165.224.221.98/pubs2005/2005046.pdf
No Child Left Behind Act of 2001. (2002). Dropout Prevention Act. Retrieved June 12, 2006, from www.ed.gov/policy/elsec/leg/esea02/pg15.html.

Olfman, S. (2005). Childhood lost: how American culture is failing our kids. Cheektowaga, NY: Greenwood Publishing Group.

Pool, C. (2002). Class size, school size. Educational Leadership, 59(5), 104.

Reutter, E. E., Jr. (1994). Race-state-education relationships. The Law of Public Education (4th ed.). Westbury, NY: The Foundation Press.

Reyes, O., Gillock, K., Kobus, K., \& Sanchez, B. (2000). A longitudinal examination of the transition into senior high school for adolescents from urban, low-income status, and predominantly minority backgrounds. American Journal of Community Psychology, 28(4), 519-544

Smith, D.T., \& DeYoung, A.J. (1988). Big school vs. small school: Conceptual, empirical, and political perspectives on the re-emerging debate. Journal of Rural and Small Schools, 3(2), 2-11.

Starkman, N., Scales, P., \& Roberts, C. (1999). Great places to learn: How asset- building schools help students succeed. MN: Search Institute.

Stanley, B., Slate, J. R., \& Jones, C. H. (1999). Study behaviors of college preparatory and honors students in the ninth grade. The High School Journal, 82(3), 165-171.

Stern, D., Raby, M., \& Dayton, C. (1992). Evolution of the academy movement. Career academies-partnerships for reconstructing American high schools. San Francisco: Jossey-Bass.

United States Department of Education. (2000). Digest of education statistics: 2000. Washington, DC: U. S. Government Printing Office.

Wheelock, A. (1993). School reform for secondary school students: A case for focusing on ninth grade. Unpublished paper.

IJEPL is a joint publication of the Association for Supervision and Curriculum Development, the Faculty of Education at Simon Fraser University, and the College of Education and Human Development at George Mason University. By virtue of their appearance in this open access journal, articles are free to use, with proper attribution, in educational and other non-commercial settings 90 days after initial publication. Copyright for articles published in IJEPL is retained by the authors. More information is available on the IJEPL Web site: http://www.ijepl.org 